\title{
Phytochemical characterization and bioactivity of ethanolic extracts on eggs of citrus blackfly
}

\section{Bruno Marcus Freire Vieira Lima ${ }^{1^{*}}$ Rosilene Aparecida de Oliveira ${ }^{2}$ Emerson Alves dos Santos ${ }^{3}$ Maria Aparecida Leão Bittencourt ${ }^{4}$ Olivia Oliveira dos Santos ${ }^{5}$}

\footnotetext{
${ }^{1}$ Universidade Estadual de Santa Cruz (UESC), Campus Soane Nazaré de Andrade, Rodovia Jorge Amado, Km 16, Salobrinho, 45662-900, Ilhéus, BA, Brasil. E-mail: brunomfvl@gmail.com. "Corresponding author.

${ }^{2}$ Departamento de Ciências Exatas, Universidade Estadual de Santa Cruz (UESC), Ilhéus, BA, Brasil.

${ }^{3}$ Ciências Biológicas, Universidade Estadual de Santa Cruz (UESC), Ilhéus, BA, Brasil.

${ }^{4}$ Departamento de Ciências Agrárias e Ambientais Rod. Jorge Amado, Universidade Estadual de Santa Cruz (UESC), Ilhéus, Bahia, Brasil.

${ }^{5}$ Doutorado em Agronomia, Universidade Estadual do Sudoeste da Bahia (UESB), Vitória da Conquista, BA, Brasil.
}

\begin{abstract}
The main objectives of this study were to determine the content of secondary metabolites (carotenoids, flavonoids, phenolic compounds, and tannins) of Argemone mexicana L., Ipomoea carnea Jacq. subsp. Fistulosa (Martius ex Choisy), Amorimia rigida (A.Juss.) W. R. Anderson, Ricinus communis L. and Syzygium aromaticum (L.) Merr. \& L. M. Perry using UV-VIS spectroscopy, and evaluating the bioactivity of the ethanolic extracts on citrus blackfly eggs (Aleurocanthus woglumi Ashby, 1915). Pera sweet orange leaves infested with citrus blackfly eggs were treated by immersion in $0.5,1.0,5.0$, and 10\%; each replicate consisted of 30 eggs. The experimental design was completely randomized, with seven treatments and four replications. Three immersions of leaves with eggs were performed, and the mortality was evaluated seven days after the procedure. Leaves were placed in Petri dishes and kept in incubators [25 $11^{\circ} \mathrm{C}$; relative humidity (RH) $60 \pm 5 \%$ and 12 hours]. S. aromaticum peduncle presented high content of tannins and phenolic compounds, while $R$. communis leaves showed high content of phenolic compounds. The commercial product Bioneem ${ }^{\circ}$ caused egg infeasibility greater than $85 \%$ at all concentrations. Treatments (10\%) that caused the greatest egg mortality were Bioneem $^{\circ}$ (94.74\%), R. communis extract (81.58\%), and the extract of S. aromaticum peduncle (80.57\%).

Key words: Aleyrodidae, Citrus blackfly, Phytochemical bioprospecting, Ricinus communis, Syzygium aromaticum.
\end{abstract}

Caracterização fitoquímica e bioatividade de extratos etanólicos em ovos de mosca-negra-dos-citros

RESUMO: Os principais objetivos deste estudo foram determinar, utilizando espectroscopia UV-VIS, os compostos secundários (carotenoides, flavonoides, compostos fenólicos e taninos) das espécies Argenome mexicana L., Ipomoea carnea Jacq. subsp. Fistulosa (Martius ex Choisy), Amorimia rigida (A.Juss.) W. R. Anderson, Ricinus communis L. e Syzygium aromaticum L. (L.) Merr. \& L. M. Perry, bem como avaliar a bioatividade de extratos etanólicos sobre ovos da mosca-negra-dos-citros (Aleurocanthus woglumi Ashby, 1915). Folhas de laranja Pêra infestadas com mosca-negra-dos-citros foram imersas nos tratamentos, a 0,5\%, 1,0\%, 5,0\% e 10\% de concentração; cada replicata foi constituida por 30 ovos. O delineamento foi inteiramente casualizado, sete tratamentos e quatro repetições. Foram realizadas três imersões das folhas com ovos, tendo sido avaliada a mortalidade sete dias após as imersões. As folhas foram alocadas em placa de Petri e mantidas em câmaras climáticas $\left(25 \pm 1{ }^{\circ} \mathrm{C}\right.$; U.R $60 \pm 5 \%$ e 12 horas). O pedúnculo do craveiro-da-india apresentou alto teor de taninos e compostos fenólicos, e folhas de mamona apresentavam alto teor de compostos fenólicos. O produto comercial Bioneem ${ }^{\circ}$, em todas as concentrações, causou inviabilidade de ovos superior a $85 \%$. Os tratamentos (10\%) que causaram a maior inviabilidade de ovos foram o Bioneem ${ }^{\circ}$ (94,74\%), o extrato de mamona (81,58\%) e o extrato do pedúnculo do craveiro-da-india $(80,57 \%)$.

Palavra-chave: Aleyrodidae, Aleurocanthus woglumi, Bioprospecção, Ricinus communis, Syzygium aromaticum.

\section{INTRODUCTION}

Citrus blackfly (Aleurocanthus woglumi Ashby, 1915), an exotic pest widely disseminated in Brazil, is capable of infecting more than 300 species including fruit trees and ornamental plants. Citrus species, considered its primary hosts, are highly susceptible to infestation by this pest (EPPO, 2008; RAGA et al., 2016; ALVIM et al., 2016). Citrus blackfly eggs are creamy white until the second day after laying, resemble curved rods, with spiral-shaped, concentrating on the abaxial surface of leaves, adhered by a short peduncle. Usually on the seventh day after laying, eggs are orange, while on the eighth day, longitudinal hatching lines are 
observed. Average incubation period lasts 15 days and mean viability is $88 \%$ at $27.4 \pm 1.1^{\circ} \mathrm{C}$ and $79.4 \pm 4.6 \%$ RH (PENA et al., 2009). Bioprospecting is essential for discovering alternative biotechnological solutions aiming to produce botanical insecticides (SACCARO JÚNIOR, 2011). The objectives of this study were to determine the content of secondary metabolites (carotenoids, flavonoids, phenolic compounds, and tannins) of Argemone mexicana L., Ipomoea carnea Jacq. subsp. Fistulosa (Martius ex Choisy), Amorimia rigida (A.Juss.) W. R. Anderson, Ricinus communis L. and Syzygium aromaticum (L.) Merr. \& L. M. Perry, and evaluate the bioactivity of the ethanolic extracts on citrus blackfly eggs.

\section{MATERIALS AND METHODS}

The exsiccates of the studied plants were deposited and registered in the Universidade Estadual de Santa Cruz (UESC) Herbarium: 19126 (Mexican poppy), 19128 (pink morning glory), 19127 (amorimia), 18835 (castor bean) and 18821 (clove tree).

Phytochemical bioprospecting of the plant extracts was carried out at the Laboratory of Natural Products and Organic Synthesis (LPPNS), at the UESC, Ilhéus, Bahia. Total phenolic compounds, total flavonoids, condensed tannins, and carotenoids were quantified using UV-VIS (Nova $\left.{ }^{\circledR} 1600 \mathrm{UV}\right)$ spectrometry of the leaves of Mexican poppy, pink morning glory, amorimia, and castor bean, and the peduncle of the clove flower buds. All analyses were performed in triplicates. Plants were dried in the shade and shredded in a blender. We used $0.2 \mathrm{~g}$ of plant material for extraction with $50 \mathrm{~mL}$ of acetone (KIMURA \& RODRIGUES-AMAYA, 2003) for the determination of carotenoids. After clarification with $\mathrm{ZnSO}_{4}$ and $\mathrm{Ba}(\mathrm{OH})_{2}$, the compound was subjected to extraction with petroleum ether, and the carotenoid content was determined spectrophotometrically at $450 \mathrm{~nm}$. For flavonoids, we extracted $0.25 \mathrm{~g}$ of plant material with methanol (PEIXOTO et al., 2008). Subsequently, we added glacial acetic acid, $2 \%$ pyridine methanolic solution, and $\mathrm{AlCl}_{3}$. After $30 \mathrm{~min}$, the spectrophotometric analysis was performed at $420 \mathrm{~nm}$. A calibration curve with 10, 30, 50, 70 and $100 \mu \mathrm{g} \mathrm{mL}^{-1}$ methanolic solutions of rutin was prepared from the standard stock solution $\left(5000 \mu \mathrm{g} \mathrm{mL}^{-1}\right)$. This curve was represented by the following equation $\mathrm{f}(\mathrm{y})=0.0075 \mathrm{x}$ $+01, r^{2}=0.9349$; the limit of detection was $0.480 \mu \mathrm{g}$ $\mathrm{mL}^{-1}$ and the limit of quantification was $1.60 \mu \mathrm{g} \mathrm{mL}^{-1}$. For determining the phenolic content, we extracted $0.3 \mathrm{~g}$ of the plant material with ethanol (FURLONG et al., 2003). After clarification with $\mathrm{ZnSO}_{4}$ and $\mathrm{Ba}(\mathrm{OH})_{2}$, the extract was reacted with Folin-Ciocalteou and $\mathrm{Na}_{2} \mathrm{CO}_{3}$.
After 30 minutes of reaction, the spectrophotometric reading was performed at $773 \mathrm{~nm}$. A calibration curve was prepared using $5,10,72.5,145.0$, and $217.5 \mu \mathrm{g} \mathrm{mL}$ ethanolic solution of gallic acid, which were was prepared from the standard stock solution $\left(5000 \mu \mathrm{g} \mathrm{mL} \mathrm{m}^{-1}\right)$. This curve was represented by the equation $\mathrm{f}(\mathrm{y})=0.0034$ $\mathrm{x}-0.0194 ; \mathrm{r}^{2}=0.9995$; the limit of detection was $1.97 \mu \mathrm{g} \mathrm{mL}^{-1}$ and the limit of quantification was $5.0 \mu \mathrm{g}$ $\mathrm{mL}^{-1}$. For the determination of condensed tannins, we extracted $0.125 \mathrm{~g}$ of plant material with $80 \%$ aqueous acetone solution, using a protocol adapted from PEREZ et al. (1999). The extract reacted with vanillin and concentrated $\mathrm{HCl}$. After $20 \mathrm{~min}$, the spectrophotometry was performed at $500 \mathrm{~nm}$. A calibration curve with 5,35, 65,95 and $125 \mu \mathrm{g} \mathrm{mL}^{-1}$ standard catechin solution was prepared from the stock solution of $140 \mu \mathrm{g} \mathrm{mL} \mathrm{m}^{-1}$. This curve was represented by the equation $\mathrm{f}(\mathrm{y})=0.0024 \mathrm{x}$ $+0.2173, \mathrm{r}^{2}=0.9990$; the limit of detection was $0.23 \mu \mathrm{g}$ $\mathrm{mL}^{-1}$ and the limit of quantification was $5.0 \mu \mathrm{g} \mathrm{mL}$.

To evaluate the bioactivity of treatments, Pera sweet orange [Citrus sinensis L. Osbeck] leaves with eggs were kept in Petri dishes with moistened filter paper and sealed with plastic film. Each sample unit consisted of 30 eggs of citrus blackfly. Leaf areas containing the eggs were demarcated (VIEIRA et al., 2013). Eggs used in these experiments were laid no longer than $24 \mathrm{~h}$ earlier, and had a creamy white appearance. The plant extracts were prepared from shredded dry material, $10 \mathrm{~g}$ of each species were removed and placed in an Erlenmeyer flask containing $100 \mathrm{~mL}$ of absolute alcohol for $8 \mathrm{~d}$. Thereafter, they were strained on filter paper and the pure ethanolic extracts $(100 \%)$ were kept in amber glass. In order to prepare the treatments, pure ethanolic extracts were diluted with distilled water to $0.5,1.0,5.0$, and $10 \%$ concentrations. Additionally, we used the commercial product Bioneem ${ }^{\odot}$ diluted at the same concentrations. Distilled water was used as a control. Three applications of each treatment $(\mathrm{n}=7)$ were made by leaf immersion ( $30 \mathrm{~s}$ per leaf). The application interval was $7 \mathrm{~s}$. Subsequently, the Petri dishes containing the leaves with eggs were closed, sealed with plastic film, identified, and allocated in BOD incubators $\left(25 \pm 1{ }^{\circ} \mathrm{C}\right.$; RU $60 \pm 5 \%$ and $12 \mathrm{~h}$ of photophase). Egg mortality was evaluated weekly under a stereoscopic microscope (56×) after the first application of the treatments. Eggs that did not hatch until the $21^{\text {st }}$ day were considered non-viable (JESUS et al., 2013, LIMA et al., 2013; VIEIRA et al., 2013).

\section{RESULTS AND DISCUSSION}

\section{Phytochemical bioprospecting}

Data on carotenoid, flavonoid, and phenolic compounds of I. carnea, R. communis, A. mexicana, 
A. rigida, and S. aromaticum are presented in figure 1.S. aromaticum showed high phenolic content, possibly due to the presence of eugenol, a volatile phenylpropanoid. It is the main compound repored in the steam of this species, as are $\beta$-caryophyllene (3.61\%) and eugenyl acetate $(3.76 \%)$, whereas $\alpha$-humolene $(0.60 \%)$ is a minor component (AFONSO et al., 2012). Further, the tannin content of this species was high (Figure 1). In the other species, negative values were obtained for tannin content, probably because the extracts were based on leaves (Figure 1). Phenolic compound level of $I$. carnea was $228.7 \mathrm{mg} \mathrm{g}^{-1}$ (Figure 1). The phenolic constituents were not identified, but some studies have reported that the catechol content is between 45 and $75 \mathrm{mg} \mathrm{g}^{-1}$ and flavonoid levels are high (SAHAYARAJ \& RAVI, 2008; KHATIWORA et al.,
2010; JAIN et al., 2016). Among the species evaluated in this study, $R$. communis had the highest flavonoid content (Figure 1). Moreover, presence of glycosides, quercetin, empferol, and kaempferol, which are phenolic compounds, have been reported in other studies (CHEN et al., 2008; PACHECO-SÁNCHEZ et al., 2012). The high content of tannins and phenolic compounds in $S$. aromaticum, and the high content of flavonoids in $R$. communis may be associated to the insecticidal potential of these species.

\section{Bioassays}

Except for the extract of $A$. mexicana, all the treatments had significant differences in citrus blackfly egg survival at $10 \%$ concentration (Table 1). Bioneem ${ }^{\odot}$ caused more than $90 \%$ egg mortality (Table 1), and a

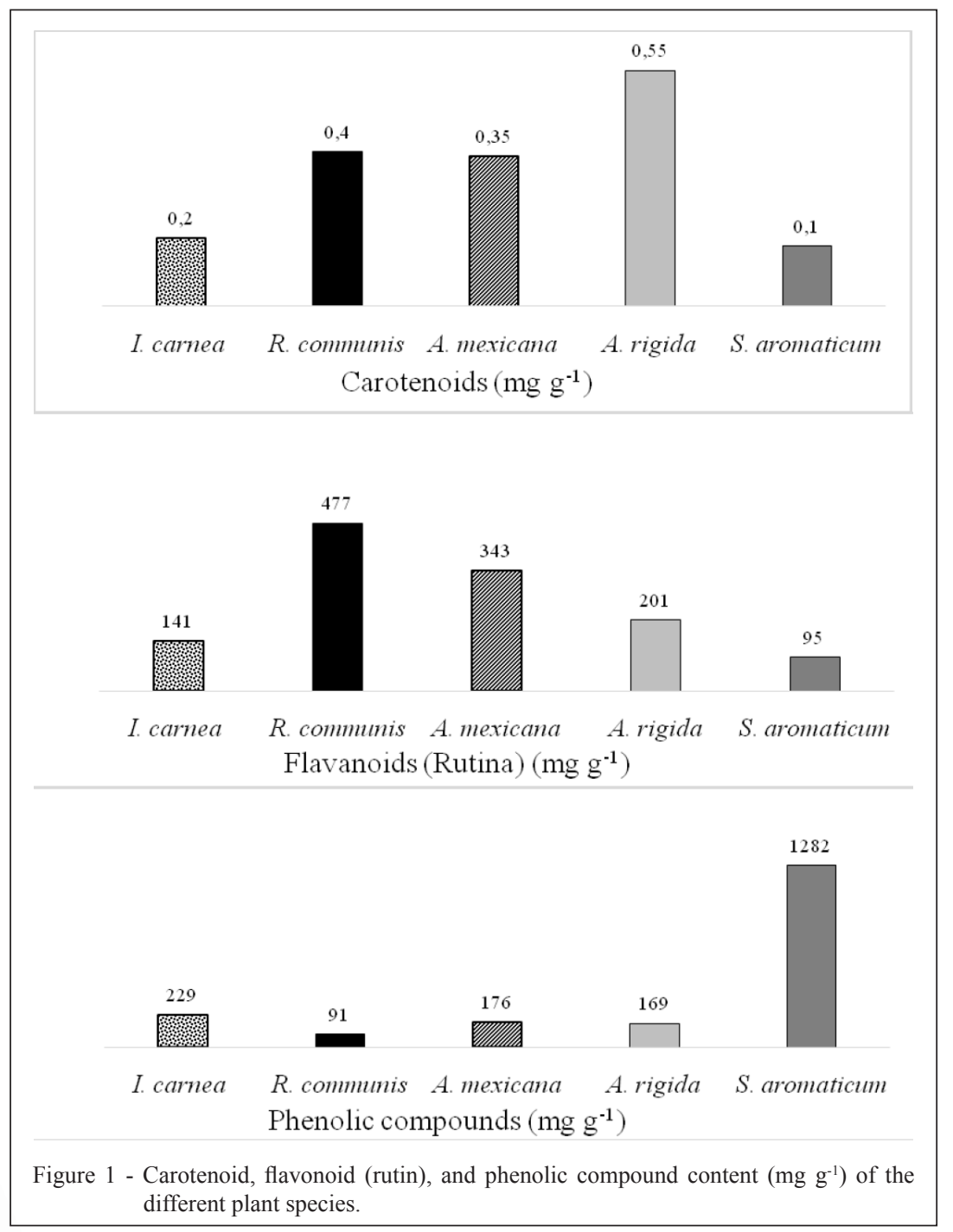

Ciência Rural, v.47, n.11, 2017. 
Table 1 - Aleurocanthus woglumi egg mortality (\%) under different treatments, after 21 days of application in laboratory $\left(25 \pm 1^{\circ} \mathrm{C}\right.$; $\mathrm{RH}$ $60 \pm 5 \%$ and $12 \mathrm{~h}$ of photophase).

\begin{tabular}{lcccc}
\hline Treatments & $0.5 \%$ & $1.0 \%$ & $5.0 \%$ & $10.0 \%$ \\
\hline I. carnea & $65.5 \% \pm 4.7 \mathrm{bB}$ & $64.5 \% \pm 8.1 \mathrm{bcB}$ & $77.6 \% \pm 6.9 \mathrm{Ba}$ & $79.1 \% \pm 6.81 \mathrm{bA}$ \\
R. communis & $60.2 \% \pm 5.14 \mathrm{bC}$ & $78.4 \% \pm 13.79 \mathrm{bB}$ & $76.4 \% \pm 14.24 \mathrm{bB}$ & $93.8 \% \pm 16.6 \mathrm{bA}$ \\
A. mexicana & $68.1 \% \pm 9.82 \mathrm{bA}$ & $74.1 \% \pm 8.29 \mathrm{bA}$ & $71.9 \% \pm 14.07 \mathrm{bcA}$ & $71.9 \% \pm 6.14 \mathrm{bcA}$ \\
A. rigida & $66.9 \% \pm 13.54 \mathrm{bA}$ & $65.5 \% \pm 15.94 \mathrm{bA}$ & $74.99 \% \pm 19.78 \mathrm{bA}$ & $77.2 \% \pm 24.37 \mathrm{bA}$ \\
S. aromaticum & $78.2 \% \pm 10.76 \mathrm{bAB}$ & $67 \% \pm 3.24 \mathrm{bB}$ & $83.9 \% \pm 10,2 \mathrm{bA}$ & $88 \% \pm 29.33 \mathrm{bA}$ \\
Bioneem & $94.1 \% \pm 19.13 \mathrm{aA}$ & $94.3 \% \pm 28.12 \mathrm{aA}$ & $96.6 \% \pm 14.20 \mathrm{aA}$ & $97.2 \% \pm 13.88 \mathrm{aA}$ \\
Control & $44.3 \% \pm 3.6 \mathrm{cA}$ & $39.5 \% \pm 3.39 \mathrm{cA}$ & $49.9 \% \pm 6.8 \mathrm{cA}$ & $56 \% \pm 3.56 \mathrm{cA}$ \\
\hline
\end{tabular}

Values followed by the same uppercase letters on the rows and lowercase letters in a column do not differ statistically from each other, according to Tukey's honestly significant difference (HSD) test at the $5 \%$ probability level.

control efficiency of more than $80 \%$ at all concentrations (Figure 2), probably due to the action of azadirachtin and other compounds present in leaves and fruit of the neem tree (MARTINEZ, 2003). After leaf immersion in Bioneem ${ }^{\circ}, 100 \%$ of citrus blackfly eggs darkened. Moreover, the commercial product Rot-Nim ${ }^{\circledR}(0.5 \%)$ has been reported to cause citrus blackfly egg mortality of $80.2 \%$ (SILVA et al., 2012), which indicated that neembased products can efficiently control citrus blackfly. Extract of $S$. aromaticum (5 and $10 \%$ only) caused egg mortality higher than $80 \%$ (Table 1) and control efficiency of greater than $80 \%$ at $10 \%$ concentration (Figure 2), possibly due to the presence of eugenol (phenolic compound) and flavonoids (AFONSO et al., 2012). The highest control efficiency $(81.6 \%)$ for the extract of $R$. communis was observed at $10 \%$ concentration (Figure 2), causing eggs mortality above $90 \%$ (Table 1). These results are supported by VIEIRA et al. (2013), who reported a decrease in the viability of citrus blackfly eggs as the commercial castor oil concentration increased. The extract of $A$. rigida caused citrus blackfly egg mortality higher than $70.0 \%$ at $5 \%$ and $10 \%$ concentrations only (Table 1). However, this species had low control efficiency (Figure 2). Furthermore, A. mexicana caused citrus blackfly egg mortality lower than $80.0 \%$ at all concentrations, which

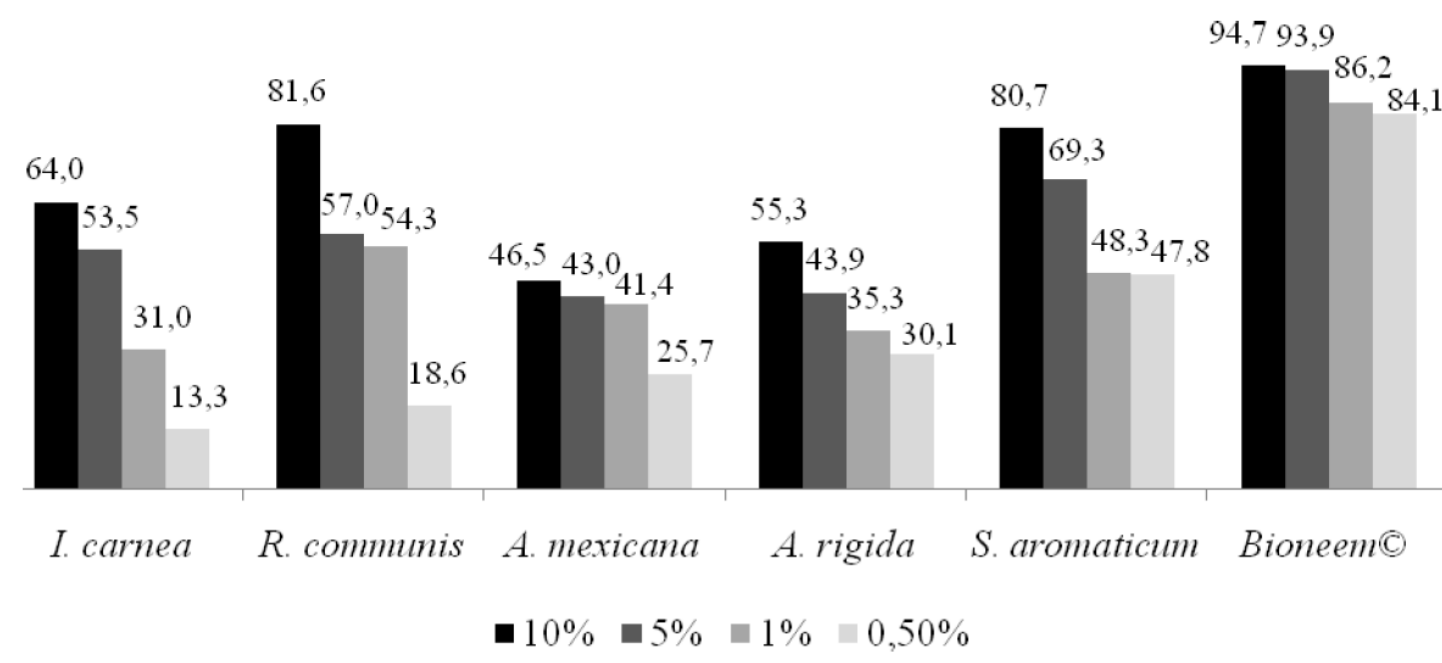

Figure 2 - Efficiency (\%) of different treatments based on plant species on egg mortality of Aleurocanthus woglumi after three applications by leaf immersion (NAKANO; SILVEIRA NETO; ZUCCHI, 1981).

Ciência Rural, v.47, n.11, 2017. 
is similar to the results obtained for $A$. rigida species (Table 1, Figure 2). MARTÍNEZ-TOMÁS et al. (2015) reported that the aqueous extract of $A$. mexicana applied to eggs of the whitefly (Hemiptera: Aleyrodidae) caused a $97.64 \%$ reduction of the nymph population. Citrus blackfly egg viability is approximately 65-95\% (PENA et al., 2009), which justifies $40 \%$ mortality in the control (Table 1 ).

\section{CONCLUSION}

The species $A$. rigida, $R$. communis, and $S$. aromaticum presented higher levels of carotenoids, flavonoids, and phenolic compounds, respectively. The commercial oil Bioneem $^{\odot}$ is effective in controlling citrus blackfly eggs. Ethanolic extracts of $S$. aromaticum and $R$. communis have insecticidal potential on citrus blackfly eggs, acting as alternative control agents for this species, besides subsidizing and contributing to its integrated management.

\section{ACKNOWLEDGMENTS}

The authors are grateful for the support of the Embrapa Cassava and Tropical Fruits and the Programa de Pósgraduação em Produção Vegetal (PPGPV).

\section{SOURCES}

Nível Superior (CAPES)

\section{REFERENCES}

ALVIM, R.G. et al. Dissemination of Aleurocanthus woglumi in citrus plants, its natural enemies and new host plants in the state of Rio de Janeiro, Brazil. Ciência Rural, v.46, n.11, p.1891-1897, 2016. Available from: <http://dx.doi.org/10.1590/0103-8478cr20151101>. Accessed: Jan. 13, 2017. doi: 10.1590/0103-8478cr20151101.

CHEN, Z. et al. Simultaneous determination of flavones and phenolic acids in the leaves of Ricinus communis Linn. by capillary electrophoresis with amperometric detection. Journal of Chromatography B, Analytical Technologies in the Biomedical and Life Sciences, v.863, n.1, p.101-106, 2008. Available from: $<$ http://dx.doi.org/10.21746/ijbio.2016.08.008>. Accessed: Jan. 19, 2017. doi: 10.1016/j.jchromb.2008.01.002.

EPPO (EUROPEAN PLANT PROTECTION ORGANIZATION). EPPO quarantine pest. Aleurocanthus woglumi. Available from: $<$ http://www.eppo.org/Quarantine/Insects/Aleurocanthus woglumi/ALECWO_dspdf>. Accessed: Feb. 08, 2017.

FURLONG, E.B. et al. Evaluation of the potential of phenolic compounds in plant Tissues. Vetor, v.13, n.1, p.105-114, 2003. Available from: <http://repositorio.furg.br/handle/1/409>. Accessed: Jan. 19, 2017

JAIN,A. et al. Evaluation of In-vitro cytotoxic and antioxidant activity of methanolic extracts of Ipomoea carnea and Alternanthera sessilis.
International Journal of Bioassays, v.5, n.8, p.4763-4766, 2016. Available from: <http://dx.doi.org/10.21746/ijbio.2016.08.008>. Accessed: Jan. 19, 2017. doi: 10.21746/ijbio.2016.08.008.

JESUS, S.C.P. de et al. Insecticide and activity of vegetal extracts on the silverleaf whitefly (Bemisia tabaci). Revista em Agronegócios e Meio Ambiente, v.6, n.1, p.117-134, 2013. Available from: $<$ http://hdl.handle.net/11449/75883>. Accessed: Jan. 19, 2017.

KHATIWORA, E. et al. Spectroscopic determination of total phenol and flavonoid contents of Ipomoea carnea. International Journal of ChemTech Research, v.2, n.3, p.1698-1701, 2010. Available from: <http://sphinxsai.com/july-sept 2010 vol2.3/ chemtech/chemtechvol2.3july-sept $210 / \mathrm{CT}=50 \% 20(1698-1701)$. pdf>. Accessed: Jan. 19, 2017.

KIMURA, M. et al. Carotenoid composition of hydroponic leafy vegetables. Journal of Agriculture and Food Chemistry, v.51, n.1, p.2603-2607, 2003. Available from: <http://hdl.handle. net/11449/67266>. Accessed: Jan. 19, 2017. doi: 10.1021/jf020539b.

LIMA, B.M.F.V. et al. Evaluation of plant extracts in the control of whitefly Bemisia tabaci biotype B in squash. Revista Ciência Agronômica, v.44, n.3, p.622-627, 2013. Available from: <http:// dx.doi.org/10.1590/S1806-66902013000300026>. Accessed: Jan. 19, 2017. doi: 10.1590/S1806-66902013000300026

MARTINEZ, S.S. The use of Nim in coffee and other cultures. Revista Agroecologia Hoje, v.4, n.21, p.13-14, 2003. Available from: <http://www.iapar.br/arquivos/File/zip_pdf/nimxcafe.pdf>. Accessed: Jan. 16, 2017.

MARTÍNEZ-TOMÁS, S.T. et al. Evaluation of three plant extracts in the whitefly population in organic tomato growing in greenhouses. Entomología Mexicana, v.2, n.1, p.371-375, 2015. Available from: $<$ http://www.entomologia.socmexent.org/revista/entomologia/2015/ EA/PAG\%20\%20371-375.pdf>. Accessed: Jan. 19, 2017.

NAKANO, O. et al. Entomologia econômica. São Paulo, Piracicaba: Livroceres, 1981. 314p.

PACHECO-SÁNCHEZ, C. et al. Effect of Ricinus communis extracts on weight and mortality of Scyphophorus acupunctatus (Coleoptera: Curculionidae). International Journal of Applied Science and Technology, v.2, n.1, p.83-94, 2012. Available from: $<$ http://www.ijastnet.com/journals/Vol_2_No_1_January_2012/11. pdf $>$. Accessed: Jan. 06, 2017.

PEIXOTO, T.J. da S.P.S. Validation of spectrophotometric methodology for quantify flavonoid content in Bauhinia cheilantha (Bongard) Steudel. Revista Brasileira de Ciências Farmacêuticas, v.44, n.4, p.683-689,2008. Available from: $<\mathrm{http}: / /$ dx.doi.org/10.1590/S1516-93322008000400015>. Accessed: Jan. 08, 2017. doi: 10.1590/S1516-93322008000400015.

PENA, M.R. et al. Biology of the citrus blackfloy, Aleurocanthus woglumi Ashby (Hemiptera: Aleyrodidae), in three host plants. Neotropical Entomology, v.38, p.254-261, 2009. Available from: <http://dx.doi.org/10.1590/S1519-566X2009000200014>. Accessed: Apr. 29, 2017. doi: 10.1590/S1519-566X2009000200014.

PEREZ, D.M. et al. Determination of the tannin content of four sorghum varieties with quantitative methods. Revista Brasileira de Zootecnia, v.28, n.3, p.453-458, 1999. Available from: <http:// dx.doi.org/10.1590/S1516-35981999000300003>. Accessed: Jan. 12, 2017. doi: 10.1590/S1516-35981999000300003. 
RAGA, A. et al. Population dynamic of citrus blackfly, Aleurocanthus woglumi (Hemiptera: Aleyrodidae), in Tahiti Lime in the eastern of the State of São Paulo, Brazil. Annual Research \& Review in Biology, v.11, n.1, p.1-7, 2016. Available from: $<$ http://www.journalrepository. org/media/journals/ARRB_32/2016/Sep/Raga1112016ARRB28668. pdf>. Accessed: Feb. 08, 2017. doi: 10.9734/ARRB/2016/28668.

SACCARO JUNIOR, N.L. The rules of access to genetic resources and benefit sharing: disputes inside and outside Brazil. Ambiente e Sociedade, v.14, n.1, p.1-16, 2011. Available from: $<$ http://dx.doi. org/10.1590/S1414-753X2011000100013>. Accessed: Jan. 19, 2017. doi: 10.1590/S1414-753X2011000100013.

SAHAYARAJ, K.; RAVI, C. Preliminary phytochemistry of Ipomea carnea jacq. and Vitex negundo Linn. Leaves. International Journal of Chemical Sciences, v.6, n.1, p.1-6, 2008. Available from: < http:// www.sadgurupublications.com/ContentPaper/2008/1_6(1)2008. pdf>. Accessed: Jan. 14, 2017.

SILVA, L.D. et al. Use of vegetable oils in the control of the citrus black fly, Aleurocanthus woglumi (Hemiptera: Aleyrodidae). Revista Colombiana Entomologia, v.38, n.2, p.182-186, 2012. Available from: <http://www.scielo.org.co/pdf/rcen/v38n2/v38n2a03.pdf>. Accessed: Jan. 19, 2017.

VIEIRA, D.L. et al. Application of commercial oils for ovicidal control of Aleurocanthus woglumi Asbhy. Bioscience Journal, v.29, n.5, p.1126-1129, 2013. Available from: $<$ http://www.seer.ufu. br/index.php/biosciencejournal/article/viewFile/21923/13006>. Accessed: Jan. 19, 2017. 